\title{
Soft Skill of Language Teachers in the Classroom: Analysis of DeVito Humanistic Interpersonal Communication Model
}

\author{
Syofia Ulfah \\ UIN Imam Bonjol Padang \\ eva_padang_07@yahoo.com
}

\begin{abstract}
Abstrac-The issue about the process of educating qualified teenagers is not easy because education nowadays demands dynamic wisdom and effort to find formulas to deal with the problems in this globalization stream. Therefore, teachers need to nurture and maintain good relationships with students and interpersonal communication skills are needed to address behavioral and disciplinary issues especially among teenagers. This study was aimed to describe that soft skill that was performed by teachers when they were in the classrooms by referring to the DeVito Humanistic Interpersonal Communication model. This was a case study involving more than one school (multiple cases) namely three Junior Hugh Schools (SMP). Three main data citing techniques were observation, interviews, and documentary evidence. The treatment of teacher's speech when communicating interpersonally with students in the classroom was analyzed interpretively-descriptively. The results of the study show that teachers have been able to use interpersonal communication skills as teachers' soft skill. The elements of interpersonal communication of the DeVito humanist model have been manifested in teacher conversation that is the element of openness, selfconcept, empathy, support, positive attitude, and accuracy.
\end{abstract}

Keywords: soft skill, language teacher; interpersonal communication; DeVito humanistic model

\section{INTRODUCTION}

It is not easy to become a beloved teacher (Yaakub \& Ayob, 1993). Beside being gentle, teachers should also realize good relationships with their students. This phenomenon requires proficiency and high commitment because to generate mutual understanding, teachers and students must be willing to share experiences and work together. This indirect relationship will close the relationship and can work together to solve problems faced by students. In this case, interpersonal communication needs attention which includes elements such as eye communication, body position and body movement, gestures or expression, clothing and physical appearance, sounds, language diversity, pause and audience engagement. The relationship between teachers and students in the classroom needs to be realized and teachers must have interpersonal communication skills to attract students' attention to understand what is trying to convey (Yusof, 2000).

Negative behavior of teenagers such as skipping school, conflicts with teachers or colleagues and not being able to pay attention to the lessons are also factors associated with learning. According to McKinney et al, (1998), teenagers will be interested to learn if they have the opportunity to be actively involved in study activities (Teaching and Learning Process) and also the interest in teaching materials that are related to the issues must be considered. The classrooms are so firm with rules and regulations discipline and serious teacher teaching approach will cause students depressed. Problems of discipline that arise from the influence of pressure such as skipping classes, vandalism and so on will cause students' achievement degenerate and motivation to learn declined (Shaffe \& Baki, 2009). Problems often caused by students such as resisting, raging, disturbing and disobeying the rules can cause teenagers at risk of becoming antisocial when becoming adults later (Novak \& Pelaez, 2004).

Teachers are also often perform mistakes in controlling student behavior. According to Barbetta, Norona \& Bicard (2003), praise needs to be given to support the students and the teacher should avoid sarcasm when advising the troubled students. Thus, the issue of the process of educating qualified teenagers is not an easy task because education nowadays demands dynamic wisdom and effort to find formulas to deal with problems in the current globalization (Puolimatka, 2008). Therefore, teachers need to nurture and maintain good relationships with students and interpersonal communication skills are needed to address behavioral and disciplinary issues especially among teenagers.

In conclusion, based on the issues discussed, this study aims to describe the soft skills that teachers perform when teachers are in the classroom by referring to DeVito's Humanistic Interpersonal Communication model. The description of KI implementation in the class is expected to provide useful inputs to all parties that the DeVito Humanistic Interpersonal Communication model can be used as an alternative soft skill to overcome student behavior, especially behavior in classroom. 


\section{METHODS}

This study was a case study. Because it involved more than one school, more precisely this study was referred as a multiple case study or known as multisite studies. This study involved three Junior High Schools (SMP). In a qualitative study, the sample was chosen purposively or purposive sampling (Miles and Huberman 1994). One way to get qualitative data that has a high degree of confidence to implement triangulation between data (Wiersma, 1991). Triangulation of data in this study through several selected ways so that the data collected really achieved high reliance, that was triangulation of field study (multiple case or multisite studies), triangulation between interview data with participants and other respondent interview data consisting from students, leaders, teachers and triangulation between interview data with observation and document analysis. Triangulation between the various fields (multiple cases or multisite studies) was one form of data triangulations with high reliance (Merriam, 2001).

The three main data collection techniques commonly used in qualitative study according to Marshall and Rosman (1995), and Wiersma (2000) are observation, interviews, and documentary evidence. It is also stated that by Yin (1994) that the scope of the study using these techniques was more convincing and precise because it was supported by information from various sources.

The process of analyzing data in a qualitative study consisted of two ranks, namely the beginning and after data collection process (Miles and Hubberman, 1984; Taylor and Bogden, 1984; Marshall and Rossman; 1989; Bogden and Biklen, 1992). The treatment of teachers' speech when communicating interpersonally with students in the class was analyzed interpretively-descriptively.

\section{FINDING AND DISCUSSION}

According to DeVito (2003), Wood (2009 and 2011) that the most important level in human communication is interpersonal communication defined as individual relationships with others in the social context. Through this process the individual adapts himself to others through roles called trasmitting and receiving. Through transmitting there is a process of communication that is message delivery (both verbal and noverbal). While the receiving occurs a process of receiving the message. The process in the interpersonal communication model is known as the linear model (one way without feedback), the interaction model (with feedback) and the last model is the transactional model which includes attitude inclusion, trust, self concept, value. Berlo (1960), DeVito (2003), Wood (2009 and 2011), Smith \& Williamson (1977) suggests that interpersonal communication is a process of interaction and sharing of meaning contained in ideas and feelings.

According to DeVito (2003) and Wood (2009 and 2011) interpersonal communication is sending a message from someone and received by others effectively and direct feedback. This type of communication is considered the most effective in an effort to shape a person's attitude, opinion or behavior because of its dialogical nature. This dialogical behavior is showed through oral communication in conversations that display a direct reverse flow. Thus, the speaker knows the response of the listener at that moment, and the speaker knows for sure whether the message sent is accepted or rejected, positively or negatively. Those involved in these interpersonal communications doubly function, each becoming a speaker and listener in turn. In the process of communication, dialogue seems to be an attempt of the perpetrator of communication for mutual understanding, empathy, mutual respect, honesty and trust.

The process of interpersonal communication is a psychological process which in turn forms a social process. Interpersonal communication here has a uniqueness because it always starts from the process of relationship that is psychological and psychological process always leads influence. DeVito (2003); Wood (2009 and 2011); argued that essentially interpersonal communication is communication between a communicator with a communicant. This type of communication is considered most effective for changing human attitudes, views, or behavior due to its dialogical process. The dialogical nature is addressed through oral communication in a conversation that displays a direct reverse. So communicators know the communicant's response at that moment, the communicator knows for sure whether the message sent is accepted or rejected, have a positive or negative impact. If not accepted, communication will give the widest opportunity to the communicant to ask.

For DeVito (2003); Wood (2009) communication has a purpose, that is to find something personal, to build meaningful relationships, to persuade, guard or influence, and entertainment. Yusof (2000) states there are three other, more specific purposes of interpersonal skills: to achieve self-will, to realize meaningful relationships, to change attitudes and behavior.

Some aspects that affect the interpersonal communication system that is interpersonal perception, self concept, and interpersonal interaction.

The influence Interpersonal Perception On Interpersonal Communication. For Wood (2009) and Fisher \& Adams (1977) interpersonal perceptions are perceptions addressed to humans. One's behavior in interpersonal communication is very dependent on perception interpersonal. If told that the new teacher is angry and does not like to be criticized, the student will be careful in asking questions.

Influence Self Concept In Interpersonal Communication. Self-concept includes what is thought and what is felt about yourself. Taylor et.al (1977, p. 83) defines self-concept as "all you think and feel about you, the entire complex of 
beliefs and attitudes you hold about yourself". Self-concept is a very decisive factor in interpersonal communication because everyone behaves as much as possible in accordance with the concept itself. When a teacher thinks of himself as a professional person, he will always try to teach them regularly, make good notes, teach earnestly so as to gain satisfaction. The tendency to behave according to self-concept is called self-fulfilling prophecy. Successful interpersonal communication depends a lot on the quality of self-concept; positive or negative. According to DeVito (2003), Emmert \& Victoria (1984) and Brooks and Emmert (1976), there are five signs of people who have the negative self-concept as follows:

1. He is sensitive to criticism: This man cannot be critized and irritable. For this person, correction is often perceived as an attempt to impose his pride. In communication, a person with a negative self-concept tends to avoid open dialogue and insists on maintaining his or her opinion with various false justifications or logic.

2. A person who has a negative self-concept, is very responsive to praise: Although he may pretend to avoid praise, he can not hide his enthusiasm at the time of receiving praise. For people like this, all sorts of forms support their self-esteem to be the center of attention. Along with his pleasures of praise, they are hypercritical to others.

3. Hypercritical Attitude: He always complains, denounces, or belittles anything and anyone. They are not smart and unable to express appreciation or acknowledgment of the strengths of others.

4. The person whose self-concept is negative, tends to feel himself unpopular with others: He feels unnoticed. Hence, he acts upon others as enemies so that they can not bear the warmth and intimacy of friendship. She will never blame herself, but will think of herself as a victim rather than a false social system.

5. People whose self-concept is negative, being pessimistic about competition as revealed in their reluctance to compete with others in making achievements. He assumes that he will not be able to resist the competition that harms himself.

Conversely, a person with a positive self-concept is characterized by things such as (a) confident in his ability to overcome problems, (b) feeling equal to others, (c) receiving praise without shame, (d) realizing that everyone has various feelings, (e) desires and behaviors that are not entirely approved by society, and (f) able to improve itself because he is able to reveal aspects of personality that he dislikes and tries to change.

In conclusion, the positive concept will be born the behavior of positive interpersonal communication as well, namely to make a more accurate perception and reveal clues that make other people interpret it as well. A positive selfconcept communicant is a person who Jourard (1971) thinks is sincere and open to others.

Interpersonal communication is effective when communications meetings are fun for communicants (DeVito 2005 and Wood 2009). When someone is together in a group that has something in common with him then he will be happy and open. Gathering with hated people will make him tense, restless and uncomfortable. He will shut down and avoid communication and want to end his communication immediately. Communication will be effective when the communicants like each other. In education, interpersonal interaction has been studied in its influence on academic achievement.

The Humanistic Interpersonal Communication Model is proposed by DeVito (2003) and sometimes this model is referred to as a "soft" model. According to this model effective interpersonal communication contains five elements, namely (a) openness, (b) empathy, (c) support, (d) positive and (e) thorough. These five elements create meaningful interpersonal relationships, honest, fulfill the needs of the soul both source and target and can satisfy both parties.

\section{Openness}

There are three aspects to opened attitude. First, the individual is able to tell others about him, including his feelings, attitudes, values and thoughts. Some people do not want to talk about themselves. As a result, attitudes are so troublesome to themselves and troublesome others if they want to establish effective relationships. Second, the individual is able to give honest feedback to what others have told him. He spoke frankly to them: what's on the head, that's what he said. Example: "Next semester I hope you will get good test results. Help me, please? I ask your help to do the exercises so that it has benefits later ". Third, the individual is able to be responsible and confess what he thinks and feels is his own thoughts and feelings, not because of the actions of others. Example: "dear my studens, it's October. In February you will be busy. My current condition is actually not possible. You can laugh for now but not later if the national examination results does not suit with what you expect ". Example: "If you do not understand, please see the example or you can also see other books ".

Jourard (1971) stated that open interpersonal communication to others indicates the person has a positive selfconcept. Self-concept is what is thought and perceived about oneself. A positive self-concept will embody the behavior of positive interpersonal communication as well. The results of the study showed that teachers have positive selfconcept. This is seen when teachers openly share their feelings. Teachers feels anxious when the students do not study 
earnestly when the time for the exam is near. The teacher asks the student's understanding and asks them to do the exercises.

\section{Emphaty}

Empathy is the element of communication that must be achieved. When an individual empathizes with another individual, he feels what that person feels, he experiences what the person experiences and he understands what that person understands. Empathy is different from pity for him, otherwise empathy means that someone is trying to sit in the person's place without feeling sorry. To feel empathy with others, there are several things that need to be done.

1. Do not judge the actions of the person is right or wrong, good or bad, ignorant or clever, sinful or innocent. Do not punish that person. Do not criticize him and do not interpret what it means. When a person does things like that, he prevents them from feeling what others feel.

2. Try to understand what makes the student feel that way. Trying to find out what his passion, what really happened to him, what things he was afraid of and more.

3. Try to imagine yourself is that person and try to feel what he feels.

After being able to empathize with that person, here are ways of conveying empathy to him:

1. Show on your own face what feelings are being experienced. If the person is sad and you can feel the sadness, try to show on his own face the sad feeling to him.

2. Show attention to him by looking at his face. With him talks by leaning toward him and if you can, sit close to him.

3. Try to touch him.

4. Tell him what he can understand and feel

Example: "This is the remnants of power. Do you want you to say this is the remnants of energy? Of course not. We must have spirit, right? " Teacher expressed his sympathy by encouraging students who are tired and sleepy because of learning Bahasa Indonesia at the last of hour lessons. The teacher uses the word 'us' to say that the teacher also feels what the student feels and hopes together to overcome the problems at hand. Teacher encouraged the students by likening the spirit of independence fighters in 1945.

Example: "Who is absent today?" No one is sick? "Teacher showed concern and care with her students by asking all the students in the classroom starting with questions about the presence and continued questions about the students' condition such as a sicks tudent.

Studies can show teachers use positive feedback to students when teachers empathize with students' circumstances. This is consistent with the opinion of English (2005) who argue empathy is the power of teachers to understand the psychology of students. Impressive interpersonal relationships are also determined by empathetic values that affect a relationship. In this case the ability to influence a person has to do with the humanitarian values involved because the emotions of both parties are necessary to produce an impressive innerpersonal relationship because teachers who communicate positively influence the students' emotions.

Like the condition of students who are tired and sleepy if the teacher would start the process of learning in the classroom. The teacher try to find out why some students were absent, what caused the students not to attend, what was going on with the student, what problems the student was having. The behavior of this teacher is strengthened by the opinion of Rashid (1999) that teachers should perform their duties as a counselor. As a teacher, it is necessary that they become an early counselor to overcome student problems, recognize and approach problematic students, guide and counsel them. Leech (1983) incorporated this teacher's sympathy to the maxim of sympathy. According to him, to give sympathy to others, one must reduce the antipathy between oneself with others. Goleman (2002) call this empathy empathy to others as emotional intelligence.

\section{Support}

Support is important in encouraging people to communicate. There are two important features in supportive communication. First, the person speaks descriptively where it is tried to explain what is actually applicable. Here, he did not at all judge what was by not saying the case was right or wrong, good or bad, clever or stupid and others appraisal like this. When a person uses the sentence of judgment he shows him judging what in front of him. The judgment sentence easily leads to disputes and the listener becomes defensive because they do not necessarily agree with the judgment made.

The second is that the individual is conversing "conditionally". A lively conversation means being open when one can not exchange his opinion if necessary. One also tries to weigh the others' opinions who may contradict one's own opinion. The layered verses give space to continue to think about the cases and keep talking about them. It also provides an opportunity for him to contribute his views and. Some people talk as if he knows all the things. Whatever the subject is talking about he has his answer. Such a person does not care about other opinions that differ from his opinion. Undocumented behavior causes others to become defensive. By that, he sparked disputes and got into a fight. Other people dislike him and distance themselves from him. They do not want to talk to them because they do not want 
to create a tense atmosphere. They do not want to express opinions because of doubt later opinion will be rejected by those who speak undocumented.

Example 1: "if you only bring your book, I already give the score. If you make an opinion and Bring book, you will get 95 more ". Example 2: "Once again I warn you. Whatever you make, whether the note or review of the book, I will give you a score. The important thing you make though still messy ". Example 3: "Yes, we thank Nadia even though she stammered. The important thing is understand. Generally speaking a ceremony is not easy. Although Nadia stammered, but she was willing to try. Hopefully for that will come more smoothly ".

The results of the study are in line with DeVito's (2003) opinion. The assessment shows that teachers are proficient in interpersonal communication when providing support to students. This is seen from the words of teachers who do not contain judgments when commenting on student behavior in doing the task. Like the teacher's words " $f$ you only bring your book, I already give the score. If you make an opinion and Bring book, you will get 95 more "even though the teacher knows there are some students who do not bring the book that the teacher requested. The teacher still uses the positive words even though he knows the student behavior is negative. The following teacher support sayings also show the same thing with the teacher's interpersonal communication above. Teacher has performed the duty as a motivator for his students (Hassan \& Mohd, 2006) and as a motivator. Teachers who have the ability to communicate like this will be able to teach effectively and teachers can attract the attention and desire of the students. Teachers may stimulate students to try to be more embarrassed and self-aware of their own mistakes without being mentioned by the teacher (Moore, 2001).

\section{Positive Attitude}

In interpersonal communication, a positive attitude is a sense of self-respect, respect for others and respect for the communication situation itself. All individual feelings are reflected in the words whether they are positive or negative. This feeling also affect the outcome of the conversation, just as someone is satisfied or dissatisfied with the conversation. Negative feelings such as anger, hatred, and hurt make communication difficult and ultimately turn off the communication.

Other people can know the person is positive or negative just by hearing the way he chooses the words he uses when speaking. Sentence the negative are the critical words and like to look for people's mistakes. Such words are easy to trigger disputes and conflicts. If he was silent, his heart ached. Perhaps the next time he does not like to interact because he wants to avoid arguments and conflicts, at least he can avoid the pain of hearing negative sentences.

One can describe a positive attitude when communicating in two ways. First by including a positive attitude using positive words. Second, by giving praise and recognition to people who interact. Giving praise is a kind of action of others. The act of composing or praising proves that someone is expressing the presence and interest of the respective person. He proves to him he is cared for and he has a place in the life of the person who praises him. Teachers can control people's egoism in two ways. First, by using words and second through actions. Example: "I am proud of this art performance you are performing". Example: "Regarding the duties yesterday, there is a lot of excitement and some even clasp it and comment on it. There are some of your friends who have been able to show important points in the story ". Or by giving a smile to him or other positive deeds.

\section{Accuracy}

Sometimes a sentence used by someone when communicating causes a person to become defensive, angry and hateful to him. Sentences that trigger quarrels and conflicts, whereas, the sentences should solve problems and close relationships. Example: "Can you hear and see? The first group debate is more devastated than the second group! They just copied from the book! "To communicate carefully, there are five things to avoid when speaking: avoid using words of necessity and obligation, avoid boasting other people's conversations because they are embarrassing to other person, avoid interrupting when people talk, and appreciate what the person said before giving your own opinion.

\section{CONCLUSION}

Interpersonal communication is the sending of a message from someone and received by others effectively and direct feedback. This type of communication is considered the most effective in an effort to shape a person's attitude, opinion or behavior because of its dialogical nature. This dialogical behavior is demonstrated through oral communication in conversations that display a direct feedback. This will be reflected in the teacher's speech when responding to student behavior when Learning Process occurs in the classroom. DeVito's Humanistic Interpesonal Communication Model helps teachers gain interpersonal communication skills of teachers that ultimately affect the relationship between teachers and students. If teachers want to have meaningful relationships with their students then the elements of interpersonal communication should be realized in teacher-student conversation that is the element of openness, self-concept, empathy, support, positive attitude, and accuracy. The assessment shows that teachers are proficient in interpersonal communication when providing support to students. This is seen from the words of teachers 
who do not contain judgments when commenting on student behavior in doing the task. Teachers are able to empathize with the state of their students and are able to use positive language to avoid conflict with students.

It is expected that the DeVito Humanist Interpersonal Communication model can be used as a soft skill instrument for teachers. The relevant agencies can use soft skill instruments to train teachers to be proficient in interpersonal communication so that they can be used to address student behavior problems in the classroom.

\section{References}

Barbetta, P.M., Norona, K.L. \& Bicard, D.F. (2003). Classroom-behavior management: A dozen common mistakes and what to do instead. Preventing School Failure, 49 (3): 11-19.

Brooks, D.W. \& Emmert, P. (1976). Interpersonal communication. Wyoming: Brown Company Publishers.

Bogden, R.C. \& Biklen, S.N. (1992). Qualitative research for education. $2^{\text {nd }}$ Edition. Needhams Height, CA: Allyn \& Bacon.

Berlo, D. K. (1960). The process of communication. New York: Holt, Rinehart \& Winston.

DeVito, J.A. (2003). Interpersonal messages. New Jersey: Pearson Education Inc.

DeVito, J.A. (2007). The Interpersonal communication book. $11^{\text {th }}$ Edition. Boston: Pearson Education Inc.

Emmert, P.,Victoria J. \& Lukasko, E. (1984). Interpersonal communication. Dubuque, Iowa: Wm. C. Brown Publishers.

Fisher, B.A. \& Adams, K.L. (1977). Interpersonal communication: Pragmatics of human relationships. $2^{\text {nd }}$ Edition. New York: McGraw-Hill.

Goleman, D. (2002). Emotional intelligence (Terj.). Jakarta: PT. Gramedia Pustaka Utama.

Hassan, A. \& M., Ainon. ( 2006). Guru sebagai pendorong di dalam bilik darjah. Kuala Lumpur: PTS Publications $\&$ Distributor Sdn. Bhd.

Jourard, M. S. (1971). Self disclosure: An experimental analysis of the transparant self. New York: Wiley \& Son.

Kasim, TSAT \& Yusof, YM. (2006). Kaidah mengajar dan kemahiran interpersonal guru. Kuala Lumpur: PTS Publications \& Distributor Sdn. Bhd.

Miles, M.B. \& Huberman, A.M. (1994). Analyzing qualitative data: A source book for new methods. Beverly Hills, CA: Sage Publication.

Marshall, C. \& Rossman, G.B. (1989). Designing qualitative research. Newbury Park, CA: Sage Publication.

Merriam, S.B. ( 2001). Validity and reliability in a qualitative research. Keynote address for. Qualitative Research Convention, Oktober 2001: Navigating Challenges, Kuala Lumpur.

Marshall, C. \& Rossman, G.B. (1995). Designing qualitative research. Newbury Park, CA: Sage Publication.

McKinney, J.P., Schiamberg, L.B. \& Shelton, L.G. (Eds.). (1998). Teaching a bout adolescent an ecological approach. New York: Garland Publishing.

Moore, D. Kenneth. (2001). Classrooms Teaching Skills. 5th Edition. McGraw-Hill

Novak, G. \& Pelaez, M. (2004). Child \& adolescent development a behavioral systems approach. Thousand Oaks, CA: Sage Publications.

Shaffe, RB, \& Baki, R. (2009). Amalan kecindan semasa sesi pengajaran dan pembelajaran dalam pengajaran dan pembelajaran daripada pelbagai perspektif. Serdang: Penerbit Universiti Putra Malaysia.

Leech, G. N. (1983). Principles of pragmatics. London: Longman.

Puolimatka, T. (2008). Max Scheler and the idea of a well rounded education. Educational Philosophy and Theory, 40 (3): 362-382.

Rashid, ARA. (1999). Profesionalisme motivasi pengurusan bilik darjah. Kuala Lumpur: Utusan Publikasi \& Distributor. Sdn. Bhd.

Smith, D.R. \& Williamson, L. K. (1977). Interpersonal communication: Roles, rules, strategies and games. New York: Brown Company Publisher.

Taylor, S.J. \& Bogden. (1984). Introduction to qualitative research methods: The search for meanings. $2^{\text {nd }}$ Edition. New York: John Wiley \& Sons.

Taylor, A. (1977). Communicating. Boston: Prentice-Hall Inc.

Wiersma, W. (2000). Research methods in education: An introduction. Boston: Allyn \& Bacon.

Wood, J.T. (2011). Communication in our lives. New Jersey: Thomson Wadsworth.

Wood, J.T. (2009). Interpersonal communication everyday encounters. $6^{\text {th }}$ Edition. New Jersey: Thomson Wadsworth.

Yaakub, NF \& Ayob, AM. (1993). Guru dan perguruan. Kuala Lumpur: Dewan Bahasa \& Pustaka.

Yin, R.K. (1994). Case study researsch: Design and methods. 2nd Edition. Thousand Oaks, CA: Sage Publication.

Yusof, Z. (2000). Sukarkah komunikasi anda? Seni berhubungan dengan orang lain. Kuala Lumpur: Utusan Publications \& Distributors Sdn. Bhd. 